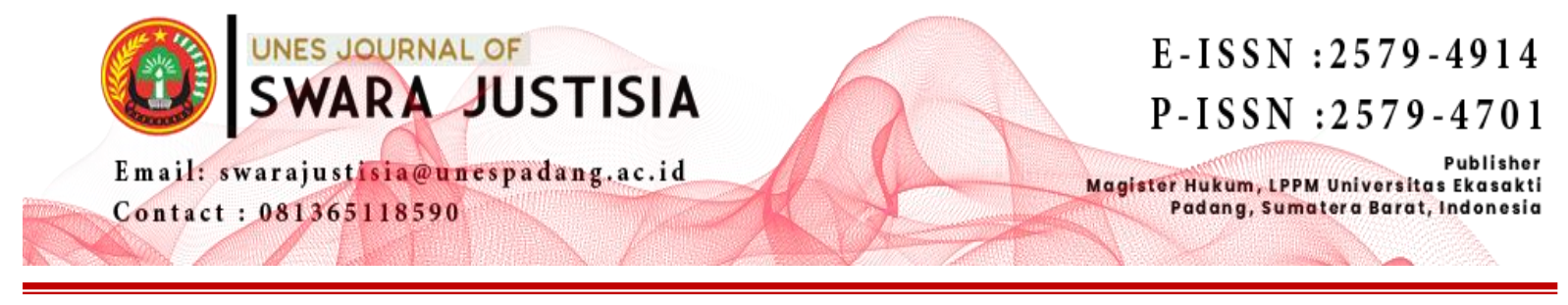

\title{
PEMBERIAN BANTUAN HUKUM KEPADA ANGGOTA POLRI PELAKU TINDAK PIDANA KEKERASAN DALAM RUMAH TANGGA DI WILAYAH HUKUM POLDA SUMBAR DI TINGKAT PENGADILAN (Studi Pada Bidang Hukum Polda Sumbar)
}

\author{
${ }^{1}$ Siti Nurmala, ${ }^{2}$ Otong Rosadi \\ ${ }^{1}$ Program Magister Ilmu Hukum,Universitas Ekasakti, Padang \\ Email: sitinurmala@gmail.com \\ ${ }^{2}$ Program Magister Ilmu Hukum,Universitas Ekasakti, Padang \\ Email: otong_rosadi@yahoo.co.uk
}

\begin{abstract}
The provision of legal assistance by the Legal Division of the Regional Police is based on the Regulation of the Head of the State Police of the Republic of Indonesia Number 2 of 2017 concerning Procedures for Providing Legal Aid by the State Police of the Republic of Indonesia. The crime of domestic violence is a complaint offense that can be given legal advice to both parties in a household dispute in the form of mediation. However, in practice there are still many parties who have not received legal assistance from the beginning of the examination of cases of domestic violence that should be accompanied to obtain their rights in the process of the case they are facing, and through mediation also because there is still no legal force for the decision of the mediation. The specification of this research is descriptive analysis. The approach used is a normative juridical approach which is supported by an empirical juridical approach with field research, namely the West Sumatra Regional Police Law Division. The data used in this study are secondary data and primary data in the form of interviews. Then the data was analyzed qualitatively and presented in a qualitative descriptive form.
\end{abstract}

Keywords: Legal Aid, Police, Domestic Violence

\begin{abstract}
ABSTRAK
Pemberian bantuan hukum oleh fungsi Bidang Hukum Kepolisian Daerah didasarkan pada Peraturan Kepala Kepolisian Negara Republik Indonesia Nomor 2 Tahun 2017 tentang Tata Cara Pemberian Bantuan Hukum Oleh Kepolisian Negara Republik Indonesia. Tindak pidana kekerasan dalam rumah tangga merupakan delik aduan yang dapat diberikan nasehat-nasehat hukum kepada kedua belah pihak yang bertikai dalam rumah tangga berupa mediasi. Namun dalam pelaksanaannya masih banyak pihak yang belum mendapatkan bantuan hukum dari awal pemeriksaan perkara kekerasan dalam rumah tangga yang seharusnya didampingi untuk mendapatkan haknya dalam proses perkara yang dihadapinya, dan secara mediasi juga dikarenakan masih belum adanya kekuatan hukum terhadap putusan dari mediasi tersebut. Spesifikasi penelitian ini adalah deskriptif analisis. Pendekatan yang digunakan adalah pendektan yuridis normatif yang didukung dengan pendekatan yuridis empiris dengan
\end{abstract}


penelitian kelapangan yaitu Bidang Hukum Polisi Daerah Sumatera Barat. Data yang digunakan dalam penelitian ini adalah data sekunder dan data primer dalam bentuk wawancara. Kemudian data tersebut dianalisis secara kualitatif dan disajikan dalam bentuk deskriptif kualitatif.

Kata Kunci: Bantuan Hukum, Polri, KDRT

\section{PENDAHULUAN}

Undang-Undang tentang Bantuan Hukum ada karena hak atas bantuan hukum telah diterima secara universal yang dijamin dalam Kovenan Internasional tentang Hak-Hak Sipil dan Politik (International Covenant on civil and Political Rights/ICCPR). Pasal 16 dan Pasal 26 ICCPR menjamin semua orang berhak memperoleh perlindungan hukum serta harus dihindarkan dari segala bentuk diskriminasi. Penyelenggaraan pemberian Bantuan Hukum kepada warga negara dalam Undang-Undang Nomor 16 Tahun 2011 tentang Bantuan Hukum merupakan upaya untuk memenuhi dan sekaligus sebagai implementasi negara hukum yang mengaku dan melindungi serta menjamin hak asasi warga negara akan kebutuhan akses terhadap keadilan (access to justice) dan kesamaan dihadapan hukum (equality before the law).

Jaminan atas hak konstitusional tersebut belum mendapat perhatian secara memadai, sehingga dibentuknya Undang-Undang tentang Bantuan Hukum ini menjadi dasar bagi negara untuk menjamin warga negara khusunya bagi orang atau kelompok orang miskin untuk mendapatkan akses keadilan dan kesamaan dihadapan hukum. Oleh karena itu, tanggung jawab negara harus diimplementasikan melalui pembentukan Undang-Undang tentang Bantuan Hukum.1Sementara itu, Pasal 54 Undang-Undang Nomor 8 Tahun 1981 tentang Kitab Undang-Undang Hukum Acara Pidana menyatakan bahwa guna kepentingan pembelaan, tersangka atau terdakwa berhak mendapat Bantuan Hukum dari seorang atau lebih penasihat hukum selama dalam waktu dan pada setiap tingkat pemeriksaan, menurut tata cara yang ditentukan dalam undang-undang.Konsep tersebut berlaku di Indonesia sejak diundangkannya Undang-undang.

KUHAP dapat dikatakan sebagai landasan bagi terselenggaranya proses peradilan pidana yang benar-benar bekerja dengan baik dan berwibawa serta benar-benar memberikan perlindungan hukum terhadap harkat marabat tersangka, tertuduh, atau terdakwa sebagai manusia.Asas-asas hukum acara pidana, antara lain: asas peradilan cepat, sederhana dan biaya ringan, asas akusator, asas pemeriksaan pengadilan terbuka untuk umum, asas praduga tak bersalah, asas mendapatkan bantuan hukum, dan asas perlakuan sama di depan hakim.

Asas mendapatkan bantuan hukum dalam Hukum Acara Pidana di Indonesia diwujudkan dalam bentuk hak. Salah satu hak yang dimiliki oleh tersangka yang terkena masalah dalam kasus pidana adalah hak untuk mendapatkan bantuan hukum. Hak ini tidak dapat dikurangi sedikitpun karena hak bantuan hukum ini telah menjadi hak mendasar yang telah dijamin oleh konstitusi Republik Indonesia berdasarkan Pasal 27 ayat (1) Juncto Pasal 28 D ayat (1) Undang-Undang Dasar Negara Republik Indonesia Tahun 1945 yang mengamanatkan bahwa setiap orang berhak atas persamaan, pengakuan, jaminan, perlindungan, dan kepastian hukum.Sistem peradilan pidana Indonesia telah menjamin

\footnotetext{
${ }^{1}$ www.jogloabang.com diakses 29 November 2020
} 
adanya peradilan yang adil (fair trail) dengan lahirnya KUHAP.KUHAP sebagai pedoman hukum acara pidana di Indonesia yang berisi ketentuan mengenai proses penyelesaian perkara pidana sekaligus menjamin hak asasi tersangka atau terdakwa dalam upaya mewujudkan proses hukum yang adil (due process of law).

Hak-hak tersangka yang terdapat dalam KUHAP dalam penulisan kali ini di khususkan pada hak untuk mendapatkan bantuan hukum yaitu Pasal 56 ayat (1) KUHAP yang berbunyi:

'Dalam hal tersangka atau terdakwa disangka atau didakwa melakukan tindak pidana yang diancam dengan pidana mati atau ancaman pidana lima belas tahun atau lebih atau bagi mereka yang tidak mampu yang diancam dengan pidana lima tahun atau lebih yang tidak mempunyai penasihat hukum sendiri, pejabat yang bersangkutan pada semua tingkat pemeriksaan dalam proses peradilan wajib menunjuk penasihat hukum bagi mereka"

Pasal 56 ayat (1) KUHAP ini seharusnya sudah dapat melengkapi pasal-pasal dalam KUHAP dalam hal pemberian bantuan hukum namun ternyata dalam pelaksanaannya Pasal 56 ayat (1) KUHAP masih terdapat berbagai hal yang perlu dikritisi, sehingga bila di rangkum ada 4 permasalahan dalam penerapan Pasal 56 ayat (1) KUHAP, yaitu:

1. Tentang kemampuan seseorang untuk memaksakan, apakah dirinya mampu menyediakan penasihat hukum.

2. Diskriminasi yang terjadi dalam Pasal 56 ayat (1) KUHAP

3. Makna kata wajib dalam Pasal 56 ayat (1) KUHAP

4. Tidak adanya konsekuensi ataupun sanksi, apabila ketentuan Pasal 56 ayat (1) KUHAP diabaikan.

Sejalan dengan KUHAP semangat yang diusung dengan berlakunya UndangUndangRepublik Indonesia Nomor 16 Tahun 2011 tentang Bantuan Hukum adalah menjamin hak asasi warga negara akan kebutuhan akses terhadap keadilan (access to justice) dan persamaan di hadapan hukum (equality before the law). Khususnya bagi orang atau kelompok orang miskin untuk mendapatkan akses keadilan dan kesamaan di hadapan hukum. Semangat yang mendasari berlakunya Undang-Undang Republik Indonesia Nomor 16 Tahun 2011 tentang Bantuan Hukum sayangnya tidak berjalan sebagai mana mestinya, karena dalam Pasal 5 ayat (1) Undang-Undang Republik Indonesia Nomor 16 Tahun 2011 tentang Bantuan Hukum menjelaskan siapa yang disebut sebagai penerima Bantuan Hukum.

Batasan pengertian Bantuan Hukum yang terdapat di dalam Pasal 1 ayat (1) UndangUndang Nomor 16 Tahun 2011 tentang Bantuan Hukum adalah Jasa hukum yang diberikan oleh pemberi bantuan hukum secara cuma-cuma kepada penerima bantuan hukum. Tujuan dari bantuan hukum adalah: ${ }^{2}$

1) Dilihat dari aspek kemanusiaan

Program bantuan hukum adalah untuk meringankan beban (biaya) dari masyarakat yang kurang mampu dalam beracara di muka pengadilan.

2) Dilihat dari aspek kesadaran hukum hlm. 8 .

\footnotetext{
${ }^{2}$ Mahkamah Agung RI. Bantuan Hukum Bagi Golongan Masyarakat Kurang Mampu. Jakarta 2004,
} 
Diharapkan bahwa program bantuan hukum akan memacu tingkat kesadaran masyarakat ke jenjang yang lebih tinggi sehingga apresiasi masyarakat terhadap hukum akan tampil melalui sikap dan perbuatanyang mencerminkan hak dan kewajibannya secara hukum.

Program bantuan hukum yang dimaksud dari pernyataan di atas tersebut adalah proses yang dilakukan untuk memberikan bantuan hukum, baik berupa pembelaan atau pendampingan dalam semua perkara yang ditangani yang akan diberikan bantuan hukum oleh fungsi Bidang Hukum Polda Sumbar, salah satunya penulis mengambil perkara pidana tindak kekerasan dalam rumah tangga yang dilakukan oleh anggota Polri di wilayah hukum Polda Sumbar, Tindak kekerasan dalam rumah tangga masih dipandang sebagai bagian dari kehidupan, sehingga sangat jarang dipandang sebagai suatu kejahatan. Setiap tahunnya tercatat kasus mengenai tindak kekerasan dalam rumah tangga yang dilakukan oleh anggota Polri di wilayah hukum Polda Sumbar meningkat, namun tidak adanya pendampingan yang didapat terhadap pelaku kekerasan rumah tangga tersebut, dikarenakan kurangnya pemahaman atau pengetahuan pelaku kekerasan rumah tangga yang dilakukan anggota polri ini terhadap hak-hak yang akan dia dapatkan ketika sedang dihadapkan dengan suatu kasus pidana khususnya perkara kekerasan dalam rumah tangga sesui judul yang penulis buat. Inilah yang menjadi salah satu problem dalam pelaksanaan bantuan hukum di salah satu lokasi penilitian di wilayah hukum Polda Sumbar. Dimana lokasi tersebut menjadi salah satu sampel berdasarkan metode yang dilakukan oleh penulis.

Bagi tersangka/terdakwa yang memperoleh jasa bantuan hukum mempunyai tujuan pada 2 (dua) hal yaitu: ${ }^{3}$

1. Sebagai syarat yang essensial untuk berjalannya fungsi maupun integritas peradilan yang baik; dan

2. Merupakan suatu tuntutan dari rasa peri-kemanusiaan.

Perlu diketahui batasan pengertian Kekerasan dalam Rumah Tangga yang terdapat didalam Pasal 1 ayat (1) Undang-Undang Nomor 23 Tahun 2004 tentang Penghapusan Kekerasan Dalam Rumah Tangga, adalah: "Setiap perbuatan terhadap seseorang terutama perempuan, yang berakibat timbulnya kesengsaraan, atau penderitaan secara fisik, seksual, psikologis, dan/atau penelantaran rumah tangga termasuk ancaman untuk melakukan perbuatan, pemaksaan, atau perampasan kemerdekaan secara melawanhukum dalam lingkup rumah tangga".

Polisi memegang peranan penting dalam melaksanakan mediasi penal.Selain peran polisi dengan diskresinya itu, pihak lain yang memiliki peranan dalam menyelesaikan perkara pidana di luar pengadilan adalah advokat. Pada penelitian ini peranan polisi pada fungsi Bidang Hukum Polda Sumbar sebagai pemberi Bantuan Hukum dalam melakukan mediasi untuk penyelesaian perkara-perkara khususnya perkara pidana kekerasan dalam rumah tangga.

Peranan tersebut diatur dalam peraturan perundang undangan.Setiap peraturan memberitahu bagaimana seorang pemegang peranan (role occupant) itu diharapkan bertindak. Bagaimana seorang itu akan bertindak sebagai respons terhadap peraturan merupakan fungsi peraturan-peraturan yang ditujukan kepadanya, sanksi-sanksinya, aktifitas dari lembaga-lembaga pelaksana serta keseluruhan komplek sosial, politik dan lain-lainnya

\footnotetext{
${ }^{3}$ Adnan Buyung Nasution, Bantuan Hukum Indonesia, LP3ES. Jakarta 1981, hlm. 5.
} 
mengenai dirinya. ${ }^{4}$ Seorang advokat haruslah selalu mengikuti perkembangan hukum, sehingga dalam mendampingi kliennya baik sebagai korban maupun sebagai pelaku kejahatan, tidak bisa hanya melihat perkara yang ditangani dengan sudut pandang law in book, tetapi juga law in action. Pasal 4 Undang-Undang Nomor 16 Tahun 2001 tentang Bantuan Hukum menentukan bahwa Bantuan Hukum yang diberikan oleh pemberi bantuan hukum meliputi masalah hukum keperdataan, pidana, dan tata usaha negara baik litigasi maupun nonlitigasi dan meliputi menjalankan kuasa, mendampingi, mewakili, membela, dan/atau melakukan tindakan hukum lain untuk kepentingan hukum Penerima Bantuan Hukum. Dengan begitu, dalam tugas dan kewajibannya, seorang advokat tidak diharuskan untuk sampai beracara dalam persidangan. Penyelesaian melalui mediasi penal adalah langkah awal dari tugasadvokat dan merupakan salah satu bentuk pemberian bantuan hukum.

Tersangka atau terdakwa anggota Kepolisian Negara Republik Indonesia berhak mendapatkan bantuan hukum pada semua tingkat pemeriksaan dalam proses peradilan ${ }^{5}$. Kepolisian Negara Republik Indonesia wajib menyediakan tenaga bantuan hukum bagi tersangka atau terdakwa anggota Kepolisian Negara Republik Indonesia yang disangka atau didakwa melakukan tindak pidana yang berkaitan dengan kepentingan tugas. Bantuan hukum sebagaimana dimaksud dalam ayat (2) dilakukan dengan memanfaatkan penasehat hukum dari institusi Kepolisian Negara Republik Indonesia dan/atau penasehat hukum lainnya. yang dikategorikan sebagai tindak pidana, antara lain ancaman terhadap keamanan dan ketertiban umum, ketenteraman, serta kesejahteraan.

Pemberian bantuan hukum oleh fungsi Bidang Hukum Kepolisian Daerah didasarkan pada Peraturan Kepala Kepolisian Negara Republik Indonesia Nomor 2 Tahun 2017 tentang Tata Cara Pemberian Bantuan Hukum Oleh Kepolisian Negara Republik Indonesia. Di lingkungan Kepolisian Republik Indonesia ("Polri"), anggota Polri yang berhadapan dengan masalah hukum berhak mendapatkan bantuan hukum berdasarkan Perkapolri Nomor 2 tahun 2017. Bantuan hukum yang diberikan oleh bidang hukum Polri adalah terhadap:

1. Institusi Polri;

2. Satuan fungsi/satuan kerja;

3. Pegawai negeri pada Polri; dan

4. Keluarga besar Polri.

Bantuan hukum yang diberikan terbatas hanya bagi lingkungan Kepolisian saja baik terhadap permasalahan hukum yang dihadapi antar lingkungan Polri ataupun persoalan antara Polri dangan masayarakat umum. Berbagai persoalan yang timbul terkadang tidak mengandung unsur perbuatan pidana yang tergolong kepada kejahatan berat atau dengan ancaman lebih dari 3 (tiga) tahun.

Terhadap persoalan yang dianggap ringan atau berat yang berkaitan dengan persoalan kekerasan dalam rumah tangga dan delik aduan diupayakan penyelesaiannya melalui mediasi penal.Pelaksanaan mediasi penal memerlukan peran aktif dari penasehat hukum yang menangani perkara tersebut, dalam hal ini adalah fungsi Bidang Hukum di Kepolisian. Berbagai persoalan dalam upaya mediasi penal antara lain adalah prinsip dalam hukum

\footnotetext{
${ }^{4}$ William J. Chambliss and Robert B. Seidman, Law order and power, Addison-Wesley Publishing Company, 1971, hlm. 123

${ }^{5}$ Peraturan Pemerintah No.3 Tahun 2003
} 
pidana yaitu berupa ganti rugi tidak menghapus sifat melawan hukum dalam tindak pidana. Selain itu, dalam hukum acara pidana, pencabutan laporan dapat dilakukan tergantung pada tindak pidananya, apakah merupakan delik aduan atau delik biasa. Apakah kesepakatan itu hanya menimbulkan kewajiban bagi tersangka untuk melakukan perbuatan yang disepakati (misalnya ganti rugi), atau sekaligus membuat pernyidik harus menghentikan pemeriksaan terhadap perkara tersebut.

Peran aktif baik dari aparat polisi maupun advokat berpengaruh dalam tercapainya kesepakatan yang adil, final dan mengikat. Maka dari itu kajian mengenai pemberian Bantuan Hukum tindak pidana kekerasan dalam rumah tangga yang dilakukan oleh anggota Polri juga menerapkan mediasi penal, perlu juga diikuti kajian mengenai akibat hukum kesepakatan damai mediasi penal. Tindak pidana yang telah diselesaikan secaramediasi oleh fungsi Bidang Hukum Polda Sumbar selama ini adalah tindak pidana, khususnya tindak pidana kekerasan dalam rumah tangga perkara yang juga merupakan delik aduan diberikan nasehatnasehat hukum kepada kedua belah pihak yang bertikai dalam rumah tangga berupa mediasi. Namun dalam pelaksanaannya masih banyak pihak yang belum mendapatkan bantuan hukum dari awal pemeriksaan perkara kekerasan dalam rumah yang seharusnya didampingi untuk mendapatkan haknya dalam proses perkara yang dihadapinya, dan secara mediasi juga dikarenakan masih belum adanya kekuatan hukum terhadap putusan dari mediasi tersebut.

Beberapa kasus pendapingan yang sudah diselesaikan oleh Fungsi Bidang Hukum Polda Sumbar masalah kekerasan dalam rumah tangga atau KDRT kebanyakan akibat dari kebutuhan seksual yang tidak terpenuhi sehingga membuat kerenggangan dalam hubungan suami istri, dan pada beberapa kasus tersebut Fungsi Bidang Hukum Polda Sumbar selalu mengusahakan dan mengupayakan mediasi sebelum kasus tersebut berlanjut pada tingkat pengadilan.

\section{METODE PENELITIAN}

Spesifikasi penelitian ini adalah deskriptif analitis yaitu penelitian yang menggambarkan tentang pemberian bantuan hukum kepada anggota Polri pelaku tindak pidana kekerasan dalam rumah tangga di wilayah hukum Polda Sumatera Barat.

Pendekatan yang akan digunakan dalam penelitian ini adalah pendekatan yuridis normatif sebagai pendekatan utama dengan didukung oleh pendekatan yuridis empiris. Pendekatan yuridis normatif yang digunakan dalam penelitian ini digunakan untuk mengkaji aturan-aturan hukum yang terkait dengan pemberian bantuan hukum kepada anggota Polri pelaku tindak pidana kekerasan dalam rumah tangga di wilayah hukum Polda Sumatera Barat. Sedangkan pendekatan yuridis empiris dalam penelitian ini digunakan untuk mengkaji aturan-aturan hukum tersebut dalam prakteknya.

\section{PEMBAHASAN}

\section{A. Pemberian Bantuan Hukum Kepada Anggota Polri Pelaku Tindak Pidana Kekerasan Dalam Rumah Tangga Di Wilayah Hukum Polda Sumbar}

Pemberian Bantuan hukum oleh bidang hukum kepolisian Daerah Sumatera Barat adalah berdasarkan Peraturan Kepala Kepolisian Negara Republik Indonesia Nomor 2 Tahun 2017 tentang Tata Cara Pemberian Bantuan Hukum Oleh Kepolisian Negara Republik Indonesia (Perkapolri 2/2017). Bantuan hukum diberikan kepadaAnggota Polri 
yang Berhadapan dengan Hukum. Bantuan Hukum adalah segala usaha, upaya, kegiatan dalam rangka membantu menyelesaikan permasalahan hukum melalui peradilan maupun di luar peradilan.

Adapun yang berhak mendapat Bantuan Hukum berdasarkan Pasal 3 Perkapolri 2/2017:

a. Institusi Polri;

b. Satuan fungsi/satuan kerja;

c. Pegawai negeri pada Polri; dan

d. Keluarga besar Polri.

Sedangkan yang disebut Penasihat Hukum/Kuasa Hukum/Pendamping adalah Pegawai Negeri pada Polri yang mendapat perintah/tugas atau kuasa dari Pimpinan Polri untukmemberikan bantuan hukum. Penasihat hukum pada bidang hukum Polda Sumbar adalah anggota Polri yang mendampingi untuk kasus peradilan perdata/pidana yang melibatkan anggota Polri lainnyaserta keluarga besar Polri.Anggota Polri dapat bertindak sebagai penasihat hukum untuk suatu perkara.

Pada Pemberian bantuan hukum dalamperkara pidana pada tingkat penyidikan, penuntutan, dan/atau semua tingkat peradilan, Penasihat Hukum/Kuasa Hukum tersebut berlatar belakang Sarjana Hukum.Bantuan Hukum menjadi tanggung jawab Kepala Bidang hukum Polda Sumbar.

Proses pemberian bantuan hukum kepada anggota Polri pelaku tindak pidana kekerasan dalam rumah tangga dimulai dari surat perintah dan surat kuasa diberikan kepada penasehat Hukum dan atau Kuasa Hukum dan atau Pendamping untuk satu perkara yang dimintakan sesuai dengan permohonan bantuan hukum oleh anggota Polri pelaku tindak pidana kekerasan dalam rumah tangga.

Seperti pada beberapa kasus yang ditangani oleh Kabidkum Polda Sumbar antara Lain:

1. AKP Hariyanto, S.H permohonan pendampingan pada tahun 2020,

2. BRIPKA Syaiful Bahri permohonan pendapat dan saran hukum pada tahun 2020 .

Pelaksanaan pemberian bantuan hukum kepada anggota polri pelaku tindak pidana kekerasan dalam rumah tangga tersebut selanjutnya pada tahap pencatatan dalam buku registrasi pada bagian bantuan Nasihat Hukum dan atau Bidang Hukum Kepolisian Daerah Sumatera Barat, selanjutnya pada tahap rencana kerja dan anggaran, mencari dan mengumpulkan alat bukti dan menganalisis; Barang bukti pada kasus AKP Hariyanto, S.H antara lain:

1. Hasil Visum Etrevertum Nomor: Ver/1090/XI/2016 Rumkit Bhayangkara Padang atas nama Aisyah Riva Sandra,

2. Hard Copy petikan putusan Mahkamah Agung Republik Indonesia Nomor 142/K/Pid.Sus/2019, tanggal 15 April 2019

3. Surat Kapolres Pasaman Nomor: B/257/III/HUK/2020 tanggal 12 Maret 2020, perihal rekomendasi dan penilaian terhadap AKP Hariyanto, S.H

Analisis atau posisi kasus AKP Hariyanto, S.H antara lain: berdasarkan putusan Mahkamah Agung Republik Indonesia Pengadilan Negeri Padang Nomor: 142 K/PID.SUS/2019 tanggal 15 April 2019 putusan perkara terduga pelanggar dengan putusan pidana penjara 4 bulan, telah melakukan perbuatan kekerasan fisik dalam lingkup 
rumah tangga sebagaimana di atur dalam Pasal 44 ayat (4) Undang-Undang Nomor 23 Tahun 2004 tentang Penghapusan Kekerasan Dalam Rumah Tangga, saudara AKP Hariyanto, S.H telah melakukan kekerasan dalam rumah tangga (KDRT) sekira tahun 2016 di Perum Permata Air Dingin Blok E No. 24 Kel. Balai Gadang Koto Tangah Padang, penyebab terjadinya KDRT terhadap istri terduga pelanggaran atas nama Eva Fitria, S.Pd. dan Aisyah Riva Sandra, karena merasa tidak dihargai dan dilayani sebagai suami seperti kebutuhan jasmani dan rohani yang tidak di berikan sehingga terjadilah kekerasan terhadap istri terduga pelanggaran yang berimbas terhadap anak kandung terduga pelanggaran.

Barang bukti pada kasus BRIPKA Syaiful Bahri antara lain:

1. Laporan Polisi Nomor: LP/163/XII/2017/Polres, tanggal 27 Oktober 2017

2. Sprindik Nomor: SP.Sidik/3/I/2019/Reskrim

3. Berkas Perkara Nomor: BP/1/I/2019 tanggal Oktober 2019

4. P-21 Nomor B-2354/N.3.13/Eku.1/10/2019 tanggal 1 Oktober 2019

5. Akte Buku Nikah Nomor Akta 0113/V/2016 tanggal 31 Mei 2016

Analisis atau posisi kasus BRIPKA Syaiful Bahri antara lain BRIPKA Syaiful Bahri dilaporkan oleh istri Tiara Sendi dugaan tindak pidana penelantaran orang lain dalam lingkup rumah tangganya, penyebab terjadinya penelantara adalah tidak adanya kecocokan antara terduga dan istrinya, istrinya tidak lagi menghargai terduga sebagai suami dan istrinya sering berpergian keluar daerah tanpa ijin dari terduga sebagai suami.

Pelaksanaan pemberian bantuan hukum kepada anggota polri pelaku tindak pidana kekerasan dalam rumah tangga tersebut selanjutnya pada tahap meminta arahan kepada Kepala Divisi Hukum Polri/Kepala Bantuan dan Nasihat Hukum Divisi Hukum Polri/Kepala Bidang Hukum Kepolisian Daerah Sumatera Barat, mengoordinasi dengan pihak ketiga dan instansi/lembaga terkait; mendaftarkan surat kuasa ke Pengadilan yang memeriksa dan mengadili perkara serta mengajukan izin insidentil beracara; mengikuti persidangan di pengadilan; meminta salinan Putusan Hakim; dan membuat laporan pelaksanaan tugas kepada Kapolri/Kepala Divisi Hukum Polri/Kepala Kepolisian DaerahSumatera Barat/Kepala Bidang Hukum Kepolisian Daerah Sumatera Barat.

Jadi, kedua contoh kasus diatas mendapatkan dan atau diberikan bantuan hukum oleh Kepala Bidang Hukum Kepolisian Daerah Sumatera Barat baik dalam bentuk bantuan hukum pendampingan, pemberian nasehat dan hingga mediasi dalam penyelesaian kasus tindak pidana kekerasan dalam rumah tangga, baik di persidangan hingga di siding disiplin dan KKEP.

\section{B. Kendala-Kendala Yang Dihadapi Oleh Fungsi Bidang Hukum Polda Sumbar Dalam Pemberian Bantuan Hukum Kepada Anggota Polri Pelaku Tindak Pidana Kekerasan Dalam Rumah Tangga Di Wilayah Hukum Polda Sumbar}

Pemberian bantuan hukum kepada anggota kepolisian pelaku tindak pidana kekerasan dalam rumah tangga merupakan bentuk perlindungan terhadap hak-hak anggota kepolisan pelaku tindak pidana, namun dalam pemberian bantuan hukum tersebut masih ada kendala-kendala yang dihadapi oleh Fungsi Bidang Hukum Polda Sumbar.

Faktor internal yang di hadapi oleh Fungsi Bidang Hukum Polda Sumbar adalah kekurang tahuan anggota kepolisian tentang adanya penyediaan bantuan hukum kepada 
anggota kepolisian dan keluarga anggota kepolisian dikarenakan kurangnya informasi atau penginformasian atau sosialisasi kepada anggota kepolisian dan atau keluarga kepolisian tengan Fungsi Bidang Hukum Polda Sumbar yang menydiakan bantuan hukum bagi setiap anggota kepolisian dan keluarga kepolisian, tidak adanya sosialisasi baik secara langsung maupun tidak langsung seperti penginformasian melalui media sehingga anggota kepolisian dan keluarga kepolisian tidak mendapatkan informasi tentang Fungsi Bidang Hukum Polda Sumbar.

Faktor eksternal yang di hadapi oleh Fungsi Bidang Hukum Polda Sumbar karena kurangnya sosialisasi sehingga anggota kepolisian dan keluarga kepolisian kurang mendapatkan informasi dan penginformasian tengang Fungsi Bidang Hukum Polda Sumbar yang berakibat masih kurangnya kepercayaan oleh anggota Polri pelaku tindak pidana kekerasan dalam rumah tangga terhadap pemberian bantuan hukum oleh Fungsi Bidang Hukum Polda Sumbar, sehingga kebanyakan anggota Polri pelaku tindak pidana hanya berangkapan bahwa pemberian bantuan hukum oleh Fungsi Bidang Hukum Polda Sumbar hanya formalitas saja. Faktor eksternal ini dapat berasal dari korban dan tersangka maupun keluarganya serta pihak-pihak lain yang terlibat dan mempengaruhi. Misalnya: korban yang tidak bersedia diselesaikan secara mediasi penal dan tetap menuntut agar kasusnya tetap dilanjutkan ke tahap selanjutnya, tersangka yang tidak kooperatif dalam pelaksanaan penyidikan sehingga menghambat proses penyidikan, tidak tercapainya kesepakatan antara korban dan tersangka maupun keluarganya. Mereka menanggap proses pemberian bantuan hukum oleh penasehat hukum yang berasal dari bidang hukum Polda Sumbar adalah upaya untuk membebaskan pelaku tindakpidana.

\section{PENUTUP}

Berdasarkan hasil penelitian, pembahasan dan analisis yang telah diuraikan pada bab sebelumnya, maka disimpulkan sebagai berikut:

1. Pemberian Bantuan Hukum Kepada Anggota Polri Pelaku Tindak Pidana Kekerasan Dalam Rumah oleh bidang hukum kepolisian Daerah Sumatera Barat adalah berdasarkan Peraturan Kepala Kepolisian Negara Republik Indonesia Nomor 2 Tahun 2017 tentang Tata Cara Pemberian Bantuan Hukum Oleh Kepolisian Negara Republik Indonesia. Pada Pemberian bantuan hukum dalam perkara pidana pada tingkat penyidikan, penuntutan, dan/atau semua tingkat peradilan, Penasihat Hukum/Kuasa Hukum tersebut berlatar belakang Sarjana Hukum. Bantuan Hukum menjadi tanggung jawab Kepala Bidang hukum Polda Sumbar. Proses pemberian bantuan hukum kepada anggota Polri pelaku tindak pidana kekerasan dalam rumah tangga dimulai dari surat perintah dan surat kuasa diberikan kepada penasehat Hukum dan atau Kuasa Hukum dan atau Pendamping untuk satu perkara yang dimintakan sesuai dengan permohonan bantuan hukum oleh anggota Polri pelaku tindak pidana kekerasan dalam rumah tangga. Selanjutnya pada tahap pencatatan dalam buku registrasi pada bagian bantuan Nasihat Hukum dan atau Bidang Hukum Kepolisian, selanjutnya pada tahap rencana kerja dan anggaran, mencari dan mengumpulkan alat bukti dan menganalisis; selanjutnya pada tahap meminta arahan kepada Kepala Divisi Hukum Polri/Kepala Bantuan dan Nasihat Hukum Divisi Hukum Polri/Kepala Bidang Hukum Kepolisian Daerah Sumatera Barat, mengoordinasi dengan pihak ketiga dan instansi/lembaga terkait; mendaftarkan surat kuasa ke Pengadilan yang 
memeriksa dan mengadili perkara serta mengajukan izin insidentil beracara; mengikuti persidangan di pengadilan; meminta salinan Putusan Hakim; dan membuat laporan pelaksanaan tugas kepada Kapolri/Kepala Divisi Hukum Polri/Kepala Kepolisian Daerah Sumatera Barat /Kepala Bidang Hukum Kepolisian Daerah Sumatera Barat.

2. Kendala-kendala yang dihadapi Bidang Hukum Polda Sumbar Dalam Pemberian Bantuan Hukum Kepada Anggota Polri Pelaku Tindak Pidana Kekerasan Dalam Rumah Tangga adalah: kendala internal masih kurangnya informasi atau penginformasian atau sosialisasi kepada anggota kepolisian dan atau keluarga kepolisian tengan Fungsi Bidang Hukum Polda Sumbar yang menyediakan bantuan hukum bagi setiap anggota kepolisian dan keluarga kepolisian, Faktor eksternal yang di hadapi oleh Fungsi Bidang Hukum Polda Sumbar karena kurangnya sosialisasi sehingga anggota kepolisian dan keluarga kepolisian kurang mendapatkan informasi dan penginformasian tengang Fungsi Bidang Hukum Polda Sumbar yang berakibat masih kurangnya kepercayaan oleh anggota Polri pelaku tindak pidana kekerasan dalam rumah tangga terhadap pemberian bantuan hukum oleh Fungsi Bidang Hukum Polda Sumbar, sehingga kebanyakan anggota Polri pelaku tindak pidana hanya berangkapan bahwa pemberian bantuan hukum oleh Fungsi Bidang Hukum Polda Sumbar hanya formalitas saja.

\section{DAFTAR PUSTAKA}

\section{Buku Teks:}

Adnan Buyung Nasution, Bantuan Hukum Indonesia, LP3ES. Jakarta 1981.

William J. Chambliss and Robert B. Seidman, Law order and power, Addison-Wesley Publishing Company, 1971.

A. Sukris Sarmadis, "Advokat" Litigasi dan Nonlitigasi Pengadilan Menjadi Advokat Indonesia Kini, Mandar Maju, Bandung, 2009.

Abdul Kadir Muhammad, Etika Profesi Hukum, Penerbit PT. Ctra Aditya Bakti, Bandung, 2001.

\section{Peraturan Perundang-Undangan:}

Undang-Undang Dasar Negara Republik Indonesia Tahun 1945.

Undang-Undang Republik Indonesia Nomor 1 Tahun 1946 tentang Peraturan Hukum Pidana, yang menyatakan berlakunya Kitab Undang-Undang Hukum Pidana.

Undang-Undang Republik Indonesia Nomor 8 Tahun 1981 tentang Hukum Acara Pidana

Undang-Undang Republik Indonesia Nomor 2 Tahun 2002 tentang Kepolisian Republik Indonesia

Undang-Undang Republik Indonesia Nomor 23 Tahun 2004 tentang Penghapusan Kekerasan dalam Rumah Tangga

Undang-Undang Republik Indonesia Nomor 16 tahun 2011 tentang Bantuan Hukum

Peraturan Kepala Kepolisian Negara Republik Indonesia Nomor 14 Tahun 2011 tentang Kode Etik Profesi Kepolisian Negara Republik Indonesia

Peraturan Kepala Kepolisian Negara Republik Indonesia Nomor 2 Tahun 2017 tentang Tata Cara Pemberian Bantuan Hukum Oleh Kepolisian Negara Republik Indonesia

Peraturan Kepala Kepolisian Negara Republik Indonesia

Nomor 14 Tahun 2018 tentang Susunan Organisasi Dan Tata Kerja Kepolisian Daerah. 